\title{
Efektivitas Penggunaan Model Problem based Learning (PBL) dan Inkuiri Terhadap Hasil Belajar Matematika Siswa SMP N 1 Kasihan Kabupaten Bantul Semester Genap Tahun Ajaran $2017 / 2018$
}

\author{
Esti Rahyu', Syariful Fahmi ${ }^{2}$ \\ ${ }^{1}$ Program studi pendidikan matematika, Universitas Ahmad Dablan Yogyakarta \\ 1,2 Program studi pendidikan matematika, Universitas Ahmad Dablan Yogyakarta \\ email: estirahayu5255@gmail.com,syariful.fahmi@pmat.uad.ac.id
}

\begin{abstract}
ABSTRAK. Pembelajaran di SMP N 1 Kasihan Kabupaten Bantul didominasi oleh guru sehingga pembelajaran yang digunakan guru kurang bervariasi. Selain itu siswa kurang aktif dalam proses pembelajaran, enggan bertanya kepada guru ketika ada materi yang belum dimengerti sehingga menyebabkan hasil belajar kurang maksimal. Penelitian ini bertujuan untuk mengetahui ada perbedaan hasil belajar matematika siswa yang menggunakan model PBL dengan hasil belajar matematika siswa yang menggunakan model Inkuiri di SMP N 1 Kasihan Bantul serta mengetahui keefektifan model PBL dan model Inkuiri terhadap hasil belajar matematika. Populasi dalam penelitian ini adalah seluruh siswa kelas VIII SMP N 1 Kasihan Kabupaten Bantul. Dengan teknik random sampling terpilih kelas sampel yaitu kelas VIII C sebagai kelas eksperimen (PBL) dan kelas VIII D sebagai kelas kontrol (Inkuir). Teknik pengumpulan data menggunakan metode tes. Instrumen pengumpulan data berupa soal uraian.Uji Instrumen pengumpulan data menggunakan uji validitas dan uji reliabilitas. Teknik analisis data yang digunakan yaitu uji prasyarat analisis meliputi uji normalitas, uji homogenitas, dan uji hipotesis dengan uji-t. Berdasarkan hasil penelitian pada dengan taraf signifikansi 5\% dan $\mathrm{dk}=59$ menunjukkan bahwa: (1) Ada perbedaan antara hasil belajar matematika siswa yang menggunakan model pembelajaran problem based learning dengan hasil belajar matematika siswa yang menggunakan model pembelajaran inquiry yang ditunjukkan dengan uji-t dua pihak thitung $=2,5068>t_{\text {tabel }}=2.0013$ dan (2) Hasil belajar matematika siswa yang mengunakan model problem based learning (PBL) lebih efektif daripada hasil belajar matematika siswa yang mengunakan model inkuiri. Hal ini ditunjukkandengan hasil uji-t satu pihak diperoleh $t_{\text {hitung }}=2,5068>\mathrm{t}_{\text {tabel }}=1,6661$.
\end{abstract}

Kata kunci: Efektivitas, PBL, Inkuiri, Hasil Belajar.

\section{PENDAHULUAN}

Pendidikan merupakan proses pembelajaran dimana peserta didik menerima dan memahami pengetahuan sebagian dari dirinya, dan kemudian mengolahnya sedemikian rupa untuk kebaikan dan kemajuan bersama (Anam, 2015). Pendidikan akan bermakna jika di dalam proses pembelajarannya mempertimbangkan perkembangan siswa. Interaksi belajar yang baik adalah guru tidak mendominasi kegiatan, tetapi membantu menciptakan kondisi yang kondusif, dan membimbing agar siswa dapat mengembangkan potensinya melalui kegiatan belajar (Fitria dan Abdul, 2015).

Kegiatan belajar mengajar di sekolah merupakan suatu kegiatan dari kegiatan pendidikan untuk membimbing siswa menuju keadaan yang lebih baik. Menurut Mutaharoh dan Abdul (2015) keberhasilan proses belajar mengajar merupakan tujuan utama dalam pendidikan di sekolah. Agar proses pembelajaran dapat berhasil diperlukan pemilihan model pembelajaran yang tepat, akan tetapi pemilihan model pembelajaran yang kurang tepat akan berpengaruh pada proses pembelajaran. Akibatnya hasil belajar matematika siswa pun kurang maksimal. 
Berdasarkan hasil wawancara dengan guru matematika di SMP N 1 Kasihan Bantul yang menjadi objek penelitian, dikatakan bahwa kurangnya keaktifan dan hasil belajar siswa dapat dilihat pada saat proses pembelajaran berlangsung. Hal itu disebabkan oleh model pembelajaran yang dipakai guru masih kurang bervariasi, dominan menggunakan model ceramah, tanya jawab dan diskusi kelompok. Model ceramah merupakan pilihan utama pada saat proses belajar setelah istirahat ataupun olahraga, karena tanpa model itu siswa sulit untuk memahami materi pembelajaran dan keterbatasan sarana serta prasarana pembelajaran. Model yang kurang bervariasi tersebut kurang melibatkan aktivitas siswa secara langsung.Sedangkan hasil belajar siswa belum optimal yang ditunjukkan oleh banyaknya siswa nilainya belum mencapai Kriteria Ketuntasan Minimal (KKM) yaitu 70, seperti ditunjukkan pada tabel 1.

Tabel 1.Rata-rata nilai Penilaian Tengah Semester ( PTS)kelas VIII Tahun Pelajaran 2017/2018

\begin{tabular}{cccccc}
\hline Kelas & Rata-rata & $\begin{array}{c}\text { Nilai } \\
\text { Tertinggi }\end{array}$ & $\begin{array}{c}\text { Nilai } \\
\text { Terendah }\end{array}$ & $\begin{array}{c}\text { Banyak siswa yang } \\
\text { mencapai KKM }\end{array}$ & $\begin{array}{c}\text { Banyak siswa yang } \\
\text { belum mencapai KKM }\end{array}$ \\
\hline VIII A & 58,52 & 87,50 & 30,00 & 7 & 25 \\
VIII B & 54,24 & 77,50 & 30,00 & 4 & 29 \\
VIII C & 52,27 & 75,00 & 25,00 & 4 & 29 \\
VIII D & 52,50 & 72,50 & 30,00 & 3 & 30 \\
VIII E & 50,45 & 72,50 & 17,50 & 2 & 31 \\
& \multicolumn{2}{c}{ Jumlah } & & 20 & 144 \\
\hline \multicolumn{7}{c}{ Persentase } & $12,195 \%$ & $87,805 \%$ \\
\hline
\end{tabular}

(Sumber: SMP N 1 Kasihan Bantul)

Berdasarkan tabel diatas, terlihat hampir sebagian besar siswa kelas VIII SMP N 1 Kasihan Kabupaten Bantul Tahun Ajaran 2017/2018 yang berada dibawah KKM. Hal ini menunjukkan bahwa hasil belajar matematika siswa masih rendah dan kurangnya motivasi belajar siswa dalam mengikuti peajaran matematika. Masalah lain yang dihadapi di SMP N 1 Kasihan Kabupaten Bantul adalah siswa masih banyak yang enggan bertanya kepada guru tentang materi pembelajaran yang belum dimengerti apalagi mereka sudah menduduki kelas VIII, adanya anggapan bahwa pembelajaran Matematika itu sulit, masih kurangnya kerjasama antar teman dalam pembelajaran, siswa terkesan bahwa guru sebagai satu-satunya sumber belajar (teachercentered learning).Selain itu, guru mengungkapkan bahwa metode pembelajaran yang digunakan juga masih mengunakan pembelajaran ekspositori pada materi matematika tertentu.

Berdasarkan hal-hal tersebut perlu dicari suatu model pembelajaran yang tepat untuk digunakan dalam pembelajaran matematika. Model Problem Based Learning (PBL) merupakan pembelajaran yang penyampaiannya dilakukan dengan cara menyajikan suatu permasalahan, mengajukan pertanyaan-pertanyaan, memfasilitasi penyelidikan, dan membuka dialog. Permasalahan yang dikaji hendaknya merupakan permasalahan kontekstual yang ditemukan oleh peserta didik dalam kehidupan sehari-hari (Sani, Ridwan, 2017).

Selain model PBL ada model inkuiri yang merupakan salah satu pembelajaran yang menggunakan pendekatan saintifik. Menurut Anam (2015) pembelajaran inkuiri menekankan kepada proses mencari dan menemukan sendiri. Pada model inkuiri siswa didorong untuk terlibat aktif dalam proses belajar mengajar, salah satunya dengan secara aktif mengajukan pertanyaan yang baik terhadap setiap materi yang disampaikan dan pertanyaan tersebut tidak harus selalu dijawab oleh guru, karena semua siswa memiliki kesempatan yang sama untuk memberikan jawaban atas pertanyaan yang diajukan.

Adapun persamaan dari kedua model tersebut yaitu model Problem Based Learning (PBL) dan model Inkviri adalah sama-sama model suatu pemecahan masalah. Dimana kedua model tersebut yaitu model Problem Based Learning (PBL) dan Inkuiri memiliki keunggulan dan kelemahan masing-masing. Berdasarkan uraian di atas maka penulis mencoba melakukan penelitian dengan 
judul "Efektivitas Pengunaan Model Problem Based Learning (PBL) dan Inkuiri Terhadap Hasil Belajar Matematika Siswa Kelas VIII SMP N 1 Kasihan Kabupaten Bantul ”.

Berdasarkan latar belakang yang dikemukakan sebelumnya, maka tujuan yang ingin dicapai dalam penelitian ini ialah. Pertama, untuk mengetahui perbedaan antara hasil belajar matematika siswa yang menggunakan model PBL dengan mengunakan model pembelajaran inkuiri pada siswa kelas VIII SMP N 1 Kasihan Kabupaten Bantul Tahun Ajaran 2017/2018. Kedua, Untuk mengetahui mana yang lebih efektif antara PBL dan model inkuiri terhadap hasil belajar matematika siswa kelas VIII SMP N 1 Kasihan Kabupaten Bantul Tahun Ajaran $2017 / 2018$.

\section{TINJAUAN LITERATUR}

\section{Model problem based learning (PBL)}

Model problem based learning (PBL) merupakan pembelajaran yang penyampaiannya dilakukan dengan cara menyajikan suatu permasalahan, mengajukan pertanaan-pertanyaan, memfasilitasi penyelidikan, dan membuka dialog. Permasalahan yang dikaji hendaknya merupakan permasalahan kontekstual yang ditemukan oleh peserta didik dalam kehidupan sehari-hari (Sani, Ridwan, 2017). Menurut Yunita dan Tri (2013) Problem Based Learning (PBL) merupakan pendekatan yang efektif untuk mengajarkan proses-proses berpikir tingkat tinggi dengan situasi berorientasi pada masalah, termasuk di dalamnya belajar bagaimana belajar. model pembelajaran Problem Based Learning (PBL), yaitu model pembelajaran yangmemberikan motivasi/dorongan kepada siswa agar dapat lebih aktif dalam melakukanproses pembelajaran, dengan konsep-konsep dan prinsip-prinsip (Evi \& Anwar, 2014). Jadi dapat disimpulkan bahwa model PBL adalah model mengajar yang mengunakan masalah yang berhubungan dengan yang nyata, kerja kelompok, umpan balik, diskusi, dan laporan akhir.Dengan demikian, siswa didorong untuk lebih aktif terlibat dalam materi pembelajaran dan mengembangkan ketrampilan berpikir kritis serta mampu mengambil kesimpulan berdasarkan pemahaman mereka.

PBL merupakan suatu model pembelajaran yang mempunyai banyak kelebihan dan kelemahan. kelebihan PBL adalah sebagai berikut: (a) pemecahan masalah dalam PBL cukup bagus untuk memahami isi pelajaran; (b) pemecahan masalah berlangsung selama proses pembelajaran menantang kemampuan siswa serta memberikan kepuasan kepada siswa; (c) PBL dapat meningkatkan aktivitas pembelajaran; (d) membantu proses transfer siswa untuk memahami masalah-masalah dalam kehidupan sehari-hari; (e) membantu siswa mengembagkan pengetahuannya dan membantu siswa untuk bertanggungjawab atas pembelajarannya sendiri; (f) membantu siswa untuk memahami hakekat belajar sebagai cara berfikir bukan hanya sekedar mengerti pem-belajaran oleh guru berdasarkan buku teks; (g) PBL menciptakan lingkungan belajar yang menyenangkan dan disukai siswa; (h) me-mungkinkan aplikasi dalam dunia nyata; dan (i) merangsang siswa untuk belajar secara kontinu. Sedangkan kelemahan PBL adalah sebagai berikut: (a) apabila siswa mengalami kegagalan atau kurang percaya diri dengan minat yang rendah mala siswa enggan untuk mencoba lagi; (b) PBL membutuhkan waktu yang cukup untuk persiapan; dan (c) pemahaman yang kurang tentang mengapa masalah-masalah yang dipe-cahkan maka siswa kurang termotivasi untuk belajar. Sanjaya (Bekti, dkk, 2013)

Langkah-langkah model problem-based learning adalah sebagai berikut: (1) tahap 1 adalah orientasi peserta didik pada masalah; (2) tahap 2 adalah mengorganisasi-kan peserta didik untuk belajar; (3) tahap 3 adalah membimbing penyelidikan individual maupun kelompok; (4) tahap adalah mengembangkan dan menyajikan hasil karya; dan (5) tahap 5 adalah menganalisis dan mengevaluasi proses pemecahan masalah (Handoyono, 2016). 
Dalam penelitian ini langkah-langkah model PBL dilaksanakan sebagai Tabel 2.

Tabel 2. Langkah - langkah Model PBL

\begin{tabular}{|c|c|c|}
\hline No & Fase & Kegiatan Guru \\
\hline 1 & $\begin{array}{l}\text { Memberikan orientasi } \\
\text { permasalahan kepada siswa }\end{array}$ & $\begin{array}{l}\text { Menyajikan permasalahan, membahas tujuan } \\
\text { pembelajaran, memaparkan kebutuhan logistik untuk } \\
\text { pembelajaran, memotivasi siswa untuk terlibat aktif }\end{array}$ \\
\hline 2 & $\begin{array}{l}\text { Mengorganisasikan } \\
\text { peserta didik untuk belajar }\end{array}$ & $\begin{array}{l}\text { Membantu siswa dalam mendefinisikan dan } \\
\text { mengorganisasikan tugas belajar/penyelidikan untuk } \\
\text { menyelesaikan permasalahan }\end{array}$ \\
\hline 3 & $\begin{array}{l}\text { Membimbing penyelidikan } \\
\text { individual maupun kelompok }\end{array}$ & $\begin{array}{l}\text { Mendorong siswa untuk memperoleh informasi yang } \\
\text { tepat, melaksanakan penyelidikan individual maupun } \\
\text { kelompok, dan mencari penjelasan solusi }\end{array}$ \\
\hline 4 & $\begin{array}{l}\text { Mengembangkan dan menyajikan } \\
\text { hasil }\end{array}$ & $\begin{array}{l}\text { Membantu siswa merencanakan produk yang tepat } \\
\text { dan relevan, seperti laporan, rekaman video, dan } \\
\text { sebagainya untuk keperluan penyampaian hasil }\end{array}$ \\
\hline 5 & $\begin{array}{l}\text { Menganalisis dan mengevaluasi } \\
\text { proses penyelidikan }\end{array}$ & $\begin{array}{l}\text { Membantu siswa melakukan refleksi terhadap } \\
\text { penyelidikan dan proses yang mereka lakukan. }\end{array}$ \\
\hline
\end{tabular}

\section{METODE}

Penelitian ini tergolong sebagai penelian Quasi Eksperimen.Adapun desain penelitian yang digunakan adalah Posttest-Only Control Design.Desain ini terdapat dua kelompok yang masingmasing dipilih secara random (R), kelompok pertama diberi perlakuan (X) dan kelompok yang lain tidak.Kelompok yang diberi perlakuan disebut kelompok eksperimen dan kelompok yang tidak diberi perlakuan disebut kelompok kontrol. Pengaruh adanya perlakuan (treatment) adalah (O1 : O2) (Sugiyono, 2011)

Penelitian ini dilaksanakan di SMP N 1 Kasihan Kabupaten Bantul. Penelitian ini akan dilaksanakan pada semester genap pada siswa kelas VIII semester genap SMP N 1 Kasihan Kabupaten Bantul tahun pelajaran 2017/2018.

Populasi dalam penelitian ini adalah siswa kelas VIII semester genap SMP N 1 Kasihan Bantul yang terdiri dari 5 kelas, yaitu kelas VIII A sebanyak 32 siswa, kelas kelas VIII B sebanyak 32 siswa, kelas kelas VIII C sebanyak sebanyak 32 siswa, kelas kelas VIII D sebanyak 32 siswa dan kelas kelas VIII E sebanyak 32 siswa. Pengambilan sampel penelitian menggunakan teknik random sampling.Dari lima kelas diambil dua kelas, melalui pengundian diperoleh kelas VIII C dan VIII D. Selanjutnya antara dua kelas tersebut diundi kembali untuk menentukan kelas eksperimen dan kelas kontrol. Di peroleh kelas VIII D sebagai kelas kontrol dan kelas VIII C sebagai kelas eksperimen yang berjumlah 32 siswa.

Variabel yang digunakan dalam penelitian ini adalah pembelajaran matematika dengan menggunaan model PBL, model inkuiri, dan hasil belajar siswa kelasVIII semester genap SMP N 1 Kasihan Kabupaten Bantul Tahun Pelajaran 2017/2018. Metode pengumpulan data dalam penelitian ini adalah mengunakan metode dokumentasi nilai Penilaian Tengah Semester ( PTS) kelas VIII SMP N 1 Kasihan Kabupaten Bantul pada mata pelajaran matematika, wawancara guru matematika dan siswa, dan tes hasil belajar matematika siswa yang berupa tes uraian.

Instrumen yang digunakan untuk pengumpulan data dalam penelitian iniberupa soal tes untuk mengetahui hasil belajar matematika diakhir penelian.Pokok bahasan dalam tes ini adalah statistika. Instrumen sebagai alat yang digunakan dalam mengambil data penelitian harus diuji cobakan terlebih dahulu.Sehingga data yang diperoleh dapat dipercaya dan dipertanggungjawabkan.Dalam hal ini uji coba instrumen yang dilakukan adalah uji validasi dan reliabilitas.Menurut sudjana (2005) ada dua langkah teknik yang digunakan dalam penelitian ini yaitu uji prasyarat analisis yang terdiri dari uji normalitas dan uji homogenitas, dan uji hipotesis yang terdiri dari uji-t dua pihak dan uji-t satu pihak. 


\section{HASIL}

Berdasarkan hasil analisis data yang peneliti lakukan diperoleh beberapa temuan. Data hasil belajar matematika pada kelas eksperimen dan kelas kontrol, terlihat pada tabel berikut:

Tabel 3. Rangkuman Deskripsi Nilai Hasil Belajar Matematika

\begin{tabular}{cccccc}
\hline Pembelajaran & $\begin{array}{c}\text { Nilai } \\
\text { Maksimal }\end{array}$ & Nilai Minimal & $\overline{\boldsymbol{X}}$ & $\boldsymbol{S}^{\mathbf{2}}$ & $\boldsymbol{S}$ \\
\hline Kelas Eksperimen & 95 & 40 & 84,5 & 139,4722 & 12,01173 \\
Kelas Kontrol & 100 & 45 & 75,83871 & 178,1998 & 13,56981 \\
\hline
\end{tabular}

Selain itu, Berdasarkan uji normalitas yang telah dilakukan dikelas eksperimen dengan derajat kebebasan 5 dan taraf signifikan 5\% maka dapat dilihat bahwa $\chi^{2}$ bitung $=6,8844<\chi^{2}$ tabel $=11,0705$ yang artinya bahwa kelas eksperimen memiliki data yang berdistribusi normal. Uji normalitas yang telah dilakukan dikelas kontrol dengan derajat kebebasan 5 dan taraf signifikan $5 \%$ maka dapart dilihat bahwa $\chi^{2}$ bitung $=5,3054<\chi^{2}$ tabel $=11,0705$ yang artinya bahwa kelas kontrol memiliki data yang berdistribusi normal. Uji homogenitas yang telah dilakukan pada kelas VIII C dan kelas VIII D dengan taraf signifikan $5 \%$ maka dapat dilihat bahwa $f_{0,95(29,30)}=$ $0,5405<F_{0}=0,7827<f_{0,05(29,30)} 1,86$ yang artinya bahwa kedua sampel berasal dari populasi yang homogen.

Selanjutnya dilakukan uji hipotesis, Berdasarkan uji hipotesis dua pihak hasil analisis yang dilakukan dengan dengan taraf signifikan 5\% dan derajat kebebasan 59, maka diperoleh nilai $t_{\text {hitung }}=2,5068 \leq t_{\text {tabel }}=2,0013 \mathrm{maka}_{0}$ ditolak $\mathrm{H}_{1}$ diterima yang artinya ada perbedaan hasil belajar matematika siswa yang mengunakan model PBL dengan hasil belajar matematika siswa yang mengunakan model inkuiri. Sedangkan uji hipotesis satu pihak hasil analisis yang dilakukan dengan dengan taraf signifikan 5\% dan derajat kebebasan 59, maka diperoleh nilai $\left.t_{\text {hitung }}=2,5068 \leq t_{\text {tabel }}=1,6661\right)$ maka $\mathrm{H}_{0}$ ditolak $\mathrm{H}_{1}$ diterima yang artinya bahwa hasil belajar matematika siswa yang menggunakan model PBL lebih baik daripada hasil belajar matematika siswa yang menggunakan model inkuiri.

\section{PEMBAHASAN}

Dalam penelitian ini, peneliti terlebih dahulu melakukan pengambilan sampel. Pengambilan sampel dilakukan dengan menggunakan teknik random sampling yaitu sampel yang diperoleh dengan cara mengundi kelas VIII semester genap SMP N 1 Kasihan Kabupaten Bantul tahun ajaran 2017/2018 yang berjumlah 5 kelas, yaitu kelas VIII A, VIII B, VIII C, VIII D dan VIII E. Dalam hal ini ditetapkan bahwa kelas VIII C sebagai kelas eksperimen yaitu kelas yang menggunakan model pembelajaran PBL dan kelas VIII D sebagai kelas kontrol yaitu kelas yang menggunakan model pembelajaran Inkuiri.

Pertemuan pertama pada kelas eksperimen, pada awalnya siswa membutuhkan waktu pada proses penyesuaian. Dalam satu kelas eksperimen dibagi menjadi 8 kelompok. Siswa pada 8 kelompok tersebut membahas LKS yang berisi materi yang sedang dipelajari. Pada saat mengisi LKS siswa mendengar pengarahan yang disampaikan sehingga siswa tidak terlalu kesulitan, dalam menyelesaikannya. Pembelajaran yang diberikan juga terlihat cukup menarik bagi siswa karena mereka tidak hanya mengerjakan soal, tetapi mereka juga menjawab soal serta menemukan jawabannya bersama dengan teman sekelompoknya. Siswa juga merasa canggung untuk mempersentasikan hasil diskusi di depan kelas. Di akhir pembelajaran guru memberi refleksi dengan bertanya mengenai materi yang baru saja di pelajari guna menilai seberapa besar kemampuan siswa dalam memahami pelajaran pada pertemuan hari itu. 
Pembelajaran kelas kontrol dilakukan sebanyak 2 kali petemuan dengan mengunakan model inkuiri. Pada awalnya pembelajaran pada kelas eksperimen mengalami sedikit hambatan. Model pembelajaran yang baru bagi siswa membutuhkan waktu untuk proses penyesuaian, karena biasanya mereka mengisi LKS yang sama dengan kelompok lain sedangkan pada pembelajaran matematika kali ini mereka mengerjakan LKS pertemuan I. Dalam satu kelas eksperimen dibagi menjadi 8 kelompok. Pada saat mengisi LKS siswa merasa kesulitan, tetapi mereka malu untuk bertanya, sehingga menyita banyak waktu untuk mengerjakan LKS tersebut. Hal inilah yang membuat pembelajaran menjadi agak lamban. Di akhir pembelajaran matematika ini guru memberikan refleksi tentang materi yang diperoleh pada saat pertemuan tersebut. Hal tersebut dilakukan supaya siswa tidak bingung dengan kesimpulan yang diperoleh dalam pembelajaran matematika.

Berdasarkan hasil penelitian dan pembahasan sebagaimana dipaparkan sebelumnya, dapat dilihat Adanya perbedaan antara hasil belajar matematika siswa yang menggunakan model pembelajaran problem based learning dengan hasil belajar matematika siswa yang menggunakan model pembelajaran inquiry siswa kelas kelas kelas VIII C dan VIII D semester SMP N 1 Kasihan Kabupaten Bantul tahun ajaran 2017/2018. Hal ini ditunjukkan dengan hasil uji hipotesis dua pihak di mana dengan taraf signifikan 5\% dan derajat kebebasan 59, maka diperoleh nilai thitung $=$ 2,5068berada diluar selang $-\mathrm{t}_{\text {tabel }}=-2,0013$ dan $\mathrm{t}_{\text {tabel }}=2,0013$.

Hasil belajar matematika siswa yang mengunakan model problem based learning (PBL) lebih efektif daripada hasil belajar matematika siswa yang mengunakan model inkuiri siswa kelas kelas VIII C dan VIII D semester genap SMP N 1 Kasihan Kabupaten Bantul tahun ajaran 2017/2018. Hal ini ditunjukkan dengan hasil uji hipotesis satu pihak di mana dengan taraf signifikan 5\% dan derajat kebebasan 59, maka diperoleh nilai thitung $=2,5068>\mathrm{t}_{\text {tabel }}=1,6661$. Hal ini berarti $\mathrm{H}_{0}$ diterima $\mathrm{H}_{1}$ ditolak.

\section{REFERENSI}

Anam, Khoirul. (2015). Pembelajaran Berbasis Inkuiri (Metode dan Aplikasi). Yogyakarta: Pustaka Belajar.

Tarisi \& Arvyaty. (2016). Perbandingan Hasil Belajar Matematika antara Siswa yang diajar dengan Model Problem Based Learning dan dengan Model Inquiry Based Learning Kelas SMP Negeri 9 Kendari. Jurnal Penelitian Pendidikan Matematika, 4(2), 29-42.

Bekti \& Herman. (2012). Pengaruh Problem-Based Learning terhadap Hasil Belajar ditinjau dari Motivasi Belajar PLC di SMK. Jurnal Pendidikan Vokasi. (3), 178-191.

Evi \& Anwar. (2014). Penerapan Model Pembelajaran Problem Based Learning dan Inquiri untuk Meningkatkan Kemampuan Berpikir Kritis Mahasiswa pada Konsep Dampak Pencemaran Lingkungan terhadap Kesehatan.Jurnal Biotik, 2(2), 77-137.

Fitria \& Abdul. (2015). Efektifitas Model Pembelajaran Kooperatif Tipe Teams Games-Tournament (TGT) terhadap Hasil Belajar Matematika Siswa kelas VII Semester Genap SMP Muhammadiyah 7 Yogyakarta Tahun Ajaran 2014/2015. AdMathEduSt, 2(3), 637-642.

Handioyono \& Zainal. (2016). Pengaruh Inquiry Learning danProblem Based Learning terhadap Hasil Belajar PKKR ditinjau dari Motivasi Belajar. Jurnal Pendidikan Vokasi. (1), 31-42

Mutoharoh \& Abdul. (2015). Efektifitas Model Pembelajaran Learning Cycle 5 E dan Group Investigastion terhadap Hasil Belajar Matematika Siswa Kelas VIII SMP Negeri 2 Mandiraja Kabupaten Banjarnegara Semester Genap Tahun Ajaran 2014/2015. AdMathEduSt, 2(3), 611618.

Sani, Ridwan. (2014). Pembelajaran Saintifik untuk Implementasi Kurikulum 2013.Jakarta: Bumi Aksara.

Sudjana.(2002). Metoda Statistika. Bandung: PT. Tarsito Bandung.

Sugiyono.(2010). Metode Penelitian Pendidikan (Pendekatan Kuantitatif, Kualitatif dan R\&D). Bandung: Alfabeta.

152 Juring: Journal for Research in Mathematics Learning, Vol. 1, No. 2, September 2018, 147 - 152 